PRZEGLĄD BIBLIOTECZNY 2019 z. 2

PL ISSN 0033-202X

MAGDALENA WÓJCIK

Instytut Studiów Informacyjnych

Uniwersytet Jagielloński

e-mail: magda.wojcik@uj.edu.pl

\title{
OBSZARY I WARIANTY WYKORZYSTANIA GIER W DZIAŁALNOŚCI BIBLIOTECZNEJ
}

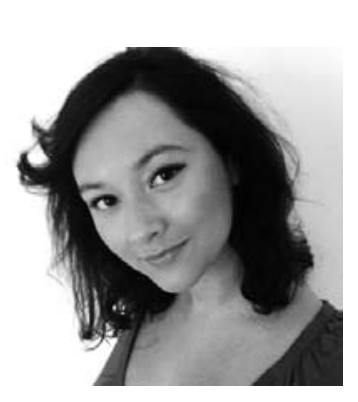

Magdalena Wójcik, dr, adiunkt w Instytucie Studiów Informacyjnych Uniwersytetu Jagiellońskiego. Jej zainteresowania badawcze obejmują problematykę nowych form komunikacji w Internecie, w tym szczególnie mediów społecznościowych i ich związków z działalnością instytucji książki. Najważniejsze publikacje to: Web 2.0 w działalności ustugowej instytucji książi (Kraków, 2013), Rozszerzona rzeczywistość - potencjał badawczy z perspektywy bibliologii i informatologii, "Przegląd Biblioteczny" 2014, R. 82, z. 4, s. 565-581 oraz The Use of Web 2.0 Services by Urban Public Libraries in Poland: Changes over the Years 2011-2013, „Libri” 2015, vol. 65, Issue 2, pp. 91-103.

SŁOWA KLUCZOWE: Biblioteki. Gry. Grywalizacja. Procesy biblioteczne. Usługi biblioteczne.

ABSTRAKT: Teza/cel - Problematyka wykorzystania gier w bibliotekach jest tematem stosunkowo często poruszanym w literaturze przedmiotu, ale głównie w odniesieniu do ich zastosowań w promocji i działaniach PR bibliotek. Brakuje opracowań pokazujących w sposób kompleksowy możliwości wykorzystania gier i procesów grywalizacji w różnych obszarach działalności bibliotek, związanych tak z obsługą użytkowników, jak i z optymalizacją procesów wewnętrznych. Celem tego artykułu jest dokonanie charakterystyki obszarów i wariantów wykorzystania gier w bibliotekach. Metoda - Zastosowano metodę analizy i krytyki piśmiennictwa. Analizie poddano literaturę przedmiotu z zakresu bibliologii i informatologii opublikowaną w latach 2008-2018 w języku polskim i angielskim, związaną z problematyką wykorzystania gier w działalności bibliotek. Podstawą wyszuki- 
wania piśmiennictwa były źródła, takie jak: katalog i bazy BN, bazy BJ, katalog WorldCat, wyszukiwarka zasobów naukowych Google Scholar przeszukująca bazy udostępniane przez rożnych wydawców oraz bazy abstraktowe BABIN i LISTA. Wyniki - Gry mogą znajdować zastosowanie $\mathrm{w}$ działalności bibliotecznej w wielu wariantach, takich jak: gry o dowolnej tematyce rozgrywane w bibliotece, gry o tematyce książkowej i bibliotecznej, gry oparte na dziełach literackich, mające potencjał dla promocji czytelnictwa, gry realizowane poza biblioteka, ale przez nią organizowane, gry wypożyczane w bibliotekach oraz książki będące grami, usługi realizowane $\mathrm{z}$ elementami grywalizacji, gry $\mathrm{w}$ działaniach edukacyjnych oraz grywalizacja procesów wewnętrznych. Wnioski - Przeprowadzona analiza pokazała, że gry mogą pełnić w bibliotece różne funkcje i być wykorzystywane zarówno dla celów edukacyjnych, promocyjnych zarówno w usługach bibliotecznych, jak i potencjalnie dla usprawniania wewnętrznych procesów bibliotecznych.

\section{WSTĘP}

Problematyka wykorzystania gry jako narzędzia promowania działalności bibliotek była stosunkowo często poruszana w literaturze przedmiotu, głównie w piśmiennictwie anglojęzycznym, szczególnie w aspekcie grywalizacji procesów edukacyjnych w bibliotece (Mayer \& Harris, 2010; Battles, Glenn \& Shedd, 2011; Margino, 2013; Vrbancic \& Byerley, 2018). Brakuje jednak opracowań pokazujących w wymiarze holistycznym możliwości wykorzystania gier w bibliotece, nie tylko w odniesieniu do promocji i edukacji, ale także w kontekście świadczenia usług dla użytkowników i organizacji wewnętrznych procesów bibliotecznych. Luka ta wymaga wypełnienia tak $\mathrm{w}$ wymiarze rozważań teoretycznych, jak i w praktyce działalności bibliotecznej. Uporządkowanie wiedzy o obszarach i formach wykorzystania gier w różnych obszarach działalności bibliotecznej może pomóc w wykorzystaniu potencjału gier i grywalizacji w większym niż dotychczas stopniu oraz przyczynić się do budowania wizerunku biblioteki jako nowoczesnej i przyjaznej instytucji.

\section{PRZEDMIOT, CEL I METODA}

Przedmiot rozważań w tym artykule stanowią możliwości wykorzystania gier i procesów grywalizacji ${ }^{1} \mathrm{w}$ działalności bibliotecznej. Celem jest dokonanie kompleksowej charakterystyki sposobów wykorzystania gier w bibliotekach. Pod uwagę wzięto przypadki takie, jak: gry o dowolnej tematyce rozgrywane w bibliotece, gry o tematyce książkowej i bibliotecznej oraz gry oparte na dziełach literackich, mające potencjał dla promocji czytelnictwa, gry realizowane poza biblioteka, ale przez nią organizowane, gry wypożyczane w bibliotekach oraz książki będące grami, usługi dla

${ }^{1}$ Alternatywne, choć rzadziej stosowane, tłumaczenia terminu gamification na język polski to: gamifikacja i gryfikacja. Na potrzeby tego tekstu przyjęto tłumaczenie "grywalizacja”. 
użytkowników realizowane z elementami grywalizacji, gry jako narzędzia działań edukacyjnych oraz grywalizacja procesów wewnętrznych.

Zastosowano metodę analizy i krytyki piśmiennictwa. Analizie poddano literaturę przedmiotu $\mathrm{z}$ zakresu bibliologii i informatologii opublikowaną w latach 2008-2018 w języku polskim i angielskim związaną $\mathrm{z}$ problematyką wykorzystania gier $\mathrm{w}$ działalności bibliotek. Podstawą wyszukiwania piśmiennictwa były źródła, takie jak: katalog i bazy BN, bazy BJ, katalog WorldCat, wyszukiwarka zasobów naukowych Google Scholar przeszukująca bazy udostępniane przez rożnych wydawców oraz bazy abstraktowe BABIN i LISTA. W oparciu o przeprowadzone wyszukiwanie dokonano analizy stanu badań oraz omówiono główne konteksty wykorzystania gier i procesów grywalizacji w bibliotekach.

W tym miejscu należy zaznaczyć, że analizie poddano wyłącznie prace, w których wykorzystanie gier i grywalizacji w bibliotece stanowiło główny temat rozważań. Problematyka wykorzystania gier $\mathrm{w}$ bibliotekach pojawia się także - w mniejszym lub $\mathrm{w}$ większym zakresie - w pracach poświęconych ogólnie promocji bibliotek, szczególnie w artykułach poświęconych nowym metodom prowadzenia kampanii promocyjnych $(\mathrm{Cu}-$ ryło, 2014; Wójcik, 2016).

\section{STAN BADAŃ}

Problematyka potencjału gier dla działań prowadzonych w bibliotekach jest stosunkowo dobrze reprezentowana zarówno w polskiej, jak i w anglojęzycznej literaturze przedmiotu, jednak tylko w wybranych aspektach. Do tematów najczęściej poruszanych w latach 2008-2018 można zaliczyć:

- gra jako element promocji i budowania wizerunku biblioteki, przede wszystkim w odniesieniu do bibliotek publicznych i akademickich (Jaskowska, 2013; Curyło, 2015; Kubisiak, 2016; Mól, 2016),

- gra jako narzędzie działań edukacyjnych, w tym jako element przysposobienia bibliotecznego i kształcenia kompetencji z zakresu information/media literacy oraz w kontekście tzw. serious games (Mayer \& Harris, 2010; Battles, Glenn \& Shedd, 2011; Margino, 2013; Vrbancic \& Byerley, 2018).

Rzadziej odnoszono się do tematów, takich jak:

- gra jako element promocji książki i czytelnictwa (Wójcik, 2014; Dongying \& Chengyue, 2017; Skrabka, 2017),

- obszary i perspektywy zastosowania gier w bibliotekach - prace przeglądowe (Bonk, 2013; Pamuła-Cieślak, 2015). Na uwagę zasługuje fakt, że problematyka wykorzystania gier $\mathrm{w}$ bibliotekach jest poruszana $\mathrm{w}$ wystąpieniach konferencyjnych - zarówno jako główny temat referatów, jak i jako poboczny wątek, np. w kontekście działań promujących bibliote- 
ki, jest także omawiana w portalach branżowych, serwisach społecznościowych czy na blogach bibliotekarskich, najczęściej w formie krótkich wpisów referujących realizowane w bibliotekach działania praktyczne. Brakuje wciąż jednak publikacji o charakterze teoretycznym i uogólniającym oraz prac referujących wyniki badań empirycznych związanych $\mathrm{z}$ wdrażaniem gier w bibliotekach. Wydaje się, że ta luka w literaturze przedmiotu powinna zostać uzupełniona.

\section{KLUCZOWE POJĘCIA}

Przed przejściem do dalszych rozważań wyjaśnienia wymaga pojęcie gry oraz koncepcja grywalizacji (ang. gamification). Gry występują współcześnie $\mathrm{w}$ wielu formach, służą realizacji różnych celów - nie tylko rozrywkowych - i są dostarczane graczom za pomocą wielu różnych nośników - fizycznych, cyfrowych i hybrydowych, dlatego też mimo istnienia $\mathrm{w}$ literaturze przedmiotu wielu propozycji definicji gry, trudno znaleźć taką, która byłaby aktualna i relewantna w stosunku do mnogości i różnorodności gier istniejących współcześnie na rynku. Jesper Juul analizując ewolucję pojęcia gry zwraca uwagę, że w tradycyjnych definicjach podkreśla się na przykład aspekt wyraźnego zdefiniowania celu gry (Juul, 2011), co nie musi być prawdziwe w odniesieniu do wielu gier opartych na module dowolności i swobodnej eksploracji środowiska gry przez użytkowników. Podkreśla się również, że według niektórych definicji gracz bierze udział w rozgrywce dla samej przyjemności gry, nie oczekując wymiernych korzyści, np. materialnych (Juul, 2011), co z kolei nie jest prawdziwe $\mathrm{w}$ odniesieniu do tzw. cyberatletów, a więc profesjonalnych graczy, ani też w odniesieniu do niektórych gier edukacyjnych czy rozgrywanych w środowisku pracy, gdzie wyniki osiągnięte $\mathrm{w}$ grze moga wymiernie przekładać się na korzyści w realnym życiu. Spośród wymienianych w definicjach cech gry, które wydają się najbardziej uniwersalne, można wymienić dobrowolny charakter rozgrywki - uczestnik może być motywowany do udziału w grze zewnętrznymi czynnikami np. środowiskiem edukacyjnym czy zawodowym, w którym się znajduje, ale udział w grze powinien być zależny od decyzji uczestnika. Charakterystyczne dla gier jest także istnienie zestawu mniej lub bardziej zdefiniowanych zasad rządzących światem gry, których przestrzeganie skutkuje nagradzaniem gracza np. zdobywaniem punktów, kolejnych poziomów zaawansowania czy odznaczeń (Adams, 2013). Podsumowując, na potrzeby tego artykułu gra została zdefiniowana jako czynność podejmowana dobrowolnie przez uczestnika w sztucznie wykreowanym świecie, który rządzi się zdefiniowanymi zasadami i często, choć nie zawsze, zakłada dążenie gracza do osiągnięcia z góry zdefiniowanego celu w toku rywalizacji i/lub kooperacji z innymi graczami lub z samym środowiskiem gry. 
Grywalizacja to najogólniej proces aplikowania mechanizmów charakterystycznych dla gier do czynności, które nie są grami, najczęściej celem pobudzenia motywacji uczestników do ich wykonania (Stobiecka \& Stobiecki, 2015). Grywalizacja jest najczęściej stosowana w edukacji, dla wspomagania procesów kształcenia na różnych poziomach, w tym także $\mathrm{w}$ edukacji dorosłych oraz w biznesie, w celu motywowania pracowników. Bazuje ona na idei dobrowolnego uczestnictwa i zakłada, że gracz - motywowany chęcią sprawdzenia własnych możliwości oraz potrzebą rywalizacji z innymi uczestnikami rozgrywki - będzie podejmował działania zmierzające do zrealizowania celu gry poprzez wykonywanie przewidzianych zadań, angażując się w wykonywanie zadań bardziej, niż gdyby realizował je poza środowiskiem gry.

\section{GRY W PRZESTRZENI BIBLIOTEKI}

Gry mogą być realizowane w bibliotece w różnych kontekstach. Biblioteka może np. udostępniać miejsce do przeprowadzenia gier komputerowych, karcianych, planszowych czy terenowych, niemających jednak związku z czytelnictwem ani realizacją bezpośrednich celów biblioteki, poza walorem promocji biblioteki jako tzw. trzeciego miejsca, a więc neutralnej przestrzeni społecznej, w której użytkownicy mogą spędzać czas w sposób przez siebie wybrany jednocześnie będąc częścią grupy i zachowując niezależność, odpoczywając od zobowiązań związanych z pracą zawodową i życiem rodzinnym (Koszowska, 2009). Na tej zasadzie w wielu bibliotekach, szczególnie publicznych, funkcjonują kluby graczy oraz odbywają się regularne rozgrywki i turnieje. Rola biblioteki ogranicza się zwykle $w$ takich przypadkach do usługi udostępnienia przestrzeni, ewentualnie zapewnienia opieki graczom w sposób nieingerujący jednak zbytnio, bez ich zgody, w przebieg rozgrywki. Tego rodzaju działania są prowadzone $\mathrm{w}$ bibliotekach stosunkowo często i choć ich celem nie jest bezpośrednio promocja czytelnictwa czy biblioteki, to jednak poprzez stworzenie użytkownikom warunków do realizacji ich zainteresowań biblioteka buduje wizerunek instytucji otwartej i przyjaznej, zapewniającej rozrywki wykraczające poza standardowe udostępnianie zbiorów.

Inne podejście prezentowane jest $\mathrm{w}$ inicjatywach polegających na organizowaniu gier w bibliotece przy aktywnym udziale bibliotekarzy. Gry takie mogą przybierać formę gier terenowych, popularnych escape rooms czy LARP (ang. live action role-playing). Istotą jest zachęcenie użytkowników do odwiedzenia biblioteki poprzez oferowanie wyjątkowych, niedostępnych w innych okolicznościach gier, które nawiązują do znanych formatów, ale jednocześnie prezentują wyjątkową fabułę, najczęściej zaprojektowaną pod kątem konkretnego wydarzenia. Celem organizacji takich wydarzeń jest promocja biblioteki, czasem także promocja czytelnictwa 
oraz budowanie korzystnego wizerunku tak samej biblioteki, jak i bibliotekarzy (często biorących aktywny udział w rozgrywkach). Przykładem takich działań może być choćby LARP organizowany w Wojewódzkiej Bibliotece Publicznej w Częstochowie dla fanów książek o Harrym Potterze (LARP Zaczytani..., 2013) czy escape room zorganizowany $\mathrm{w}$ czasie Tygodnia Bibliotek przez Bibliotekę Akademii Morskiej w Gdańsku, który cieszył się wyjątkowym powodzeniem i został ogłoszony najlepszym wydarzeniem Tygodnia Bibliotek 2015 (Tydzień Bibliotek..., 2015). Organizacja gier, szczególnie tych o tematyce związanej z książka, czytelnictwem czy samą biblioteka, jest dobrą strategią na przyciągnięcie użytkowników do budynku biblioteki, tak, by zapewnić im możliwość zapoznania się nie tylko z jej ofertą online, ale także z usługami biblioteki dostępnymi na miejscu.

\section{GRY O BIBLIOTECE}

Gry mogą stanowić narzędzie promocji czytelnictwa i bibliotek jako instytucji nie tylko przez fakt ich rozgrywania w środowisku bibliotecznym czy udział bibliotekarzy w rozgrywkach, ale także przez samą tematykę. Gry o tematyce bibliotecznej nie są bardzo popularne, częściej biblioteka występuje jako element środowiska gry niż główny temat rozgrywki, ale można znaleźć takie przykłady. Jedną z gier planszowych, nawiązujących do bibliotek w wymiarze historycznym, jest Skryptorium, gra dystrybuowana przez Opactwo Benedyktynów w Tyńcu (Gra planszowa...). Zadaniem gracza jest zebranie średniowiecznych manuskryptów i dostarczenie ich do tytułowego skryptorium. Gra prezentuje wprawdzie bardzo tradycyjny obraz specyficznego typu biblioteki (średniowiecznej biblioteki klasztornej), co nie oddaje dobrze współczesnej roli tych instytucji, niemniej jednak może wzbudzić zainteresowanie starą książką i przyczynić się do promocji wiedzy na ten temat, szczególnie wśród młodszych użytkowników, do których głównie jest kierowana. Kolejnym przykładem jest gra mobilna „Tajemnica biblioteki”, bazująca na książce pod tym samym tytułem, będącej częścią popularnego cyklu powieści detektywistycznych autorstwa Martina Widmarka i Heleny Willis. Udział wymaga posiadania urządzenia przenośnego typu tablet lub smartfon; gra jest rozgrywana częściowo w budynku bibliotecznym. Uczestnicy mają za zadanie rozwiązać tajemnicę zniknięcia cennych książek z biblioteki m.in. w toku zbierania odpowiednich wskazówek i rozmów z bibliotekarką jedną z bohaterek gry (Gra mobilna..., 2018).

Dobrze zaprojektowane gry o tematyce bibliotecznej mogą przyczynić się do promocji tych instytucji i pomóc w budowaniu ich korzystnego wizerunku, jak również pomóc w popularyzacji wiedzy na temat zawodu bibliotekarza. W tym kontekście ważne wydaje się zintensyfikowanie 
działań w zakresie projektowania gier o tematyce bibliotecznej, które pokazywałyby obraz współczesnej biblioteki i zawód bibliotekarza w atrakcyjny sposób, wzbudzający zainteresowanie tym obszarem działalności profesjonalnej.

\section{GRY OPARTE NA KSIĄŻKACH}

Jedną z form promocji czytelnictwa - realizowanej niezależnie od bibliotek lub niekiedy $\mathrm{z}$ ich udziałem - są bez wątpienia gry bazujące na znanych utworach literackich. Przyczyniają się one często - podobnie jak oparte na książkach filmy czy seriale - do ich ponownego odkrycia przez czytelników. Przykładem może być choćby gra planszowa „Gra o tron”, nawiązująca do książek G.R.R. Martina, gra komputerowa „Harry Potter" - bazująca na serii książek J.K. Rowling, gra planszowa „W pustyni i w puszczy" oparta na klasycznej powieści Henryka Sienkiewicza czy gra komputerowa „Władca pierścieni” oparta na trylogii J.R.R. Tolkiena. Na szczególną uwagę zasługuje jednak gra komputerowa „Wiedźmin” (i jej kolejne części), nawiązująca do książek Andrzeja Sapkowskiego, która zyskała olbrzymią popularność na całym świecie (trzecia część cyklu zyskała prestiżowy tytuł gry roku) i przyczyniła się z jednej strony, do wzrostu popularności książek wydanych pierwotnie w latach 90 . XX wieku wśród kolejnych pokoleń czytelników w kraju, z drugiej - przyczyniła się do promocji polskiej fantastyki za granicą (Zdanowicz, 2015). Przytoczone przykłady pozwalają sądzić, że udostępnienie w bibliotekach gier opartych na dziełach literackich może być zarówno dobrą formą promocji starszych pozycji książkowych wśród młodych czytelników, jak również formą promocji samych bibliotek jako instytucji udostępniających gry i ich książkowe pierwowzory.

\section{GRY POZA BIBLIOTEKA}

Popularnym sposobem promocji zarówno książki, jak i samych bibliotek są gry organizowane przez biblioteki, ale poza ich siedzibami. Przykładem takiego podejścia są popularne w ostatnich latach gry terenowe, realizowane albo - $\mathrm{w}$ modelu bardziej tradycyjnym - poprzez rozwiązywanie przez uczestników zadań i zagadek rozmieszczonych fizycznie w przestrzeni miejskiej, albo z wykorzystaniem nowych technologii, np. rozszerzonej rzeczywistości, która pozwala nakładać na obraz realnie istniejących miejsc, dodatkową cyfrową warstwę informacyjną. Gry realizowane poza budynkiem, pozwalają pokonać ograniczenia lokalowe, z którymi zmaga się wiele bibliotek i zaprezentować szerokiej publiczności obraz bibliotek jako nowoczesnych instytucji, które potrafią zapewnić użytkownikom ciekawe sposoby spędzania wolnego czasu. Tematyka 
gier najczęściej nawiązuje do konkretnych dzieł lub gatunków literackich albo dotyczy samych bibliotek i ma na celu ich promocję. Przykładem takich inicjatyw może być choćby literacka gra miejska „Kryminalne zagadki Oświęcimia", zorganizowana przez Miejską Bibliotekę Publiczną w Oświęcimiu (Gra miejska..., 2015) czy gra „Biblioteka inspiruje”, zorganizowana przez Miejską Bibliotekę Publiczną w Chrzanowie (Biblioteka inspiruje..., 2016). Podobne inicjatywy organizowane są nie tylko w bibliotekach publicznych, ale także w bibliotekach akademickich (Curyło, 2015), pedagogicznych czy szkolnych (Gra miejska..., 2016).

\section{GRYWALIZACJA ZASOBÓW I USŁUG}

Można grywalizować także samą ofertę biblioteczną. Biblioteki nie tylko gromadzą i wypożyczają gry, ale także oferują książki mające charakter gier. Przykładem takiego podejścia jest udostępnianie książek konwergencyjnych, posiadających swoje multimedialne rozszerzenia oraz przede wszystkim - książek bazujących na technologii step-in-book, które łączą przekaz tekstowy z warstwą multimedialną i elementami grywalizacji. Użytkownik chcąc poznać fabułę musi wejść w interakcję z książką i wykonywać określone czynności np. zapukać, by otworzyły się drzwi czy krzyknąć, by zwrócić czyjąś uwagę (Przybyszewska, 2017). Udostępnianie książek typu step-in-book jest dobrym przykładem włączania elementów gry i grywalizacji do oferty bibliotecznej.

Grywalizacja usług nie jest tematem często podejmowanym w literaturze przedmiotu. Można znaleźć prace poruszające problematykę wykorzystania elementów grywalizacji w promowaniu [podkreśl. M. Wójcik] usług bibliotecznych (Jaskowska, 2013), ale trudno już znaleźć opisy realizowanych w praktyce przykładów grywalizacji samych usług. Procesy udostępniania zbiorów, realizacji kwerend czy usług informacyjnych rzadko realizowane są w sposób odbiegający od standardowego - zmieniają się wprawdzie narzędzia realizacji usług, np. część oferty udostępniana jest online lub za pomocą aplikacji mobilnych, ale grywalizacja procesów usługowych nie jest zjawiskiem, które byłoby widoczne i opisywane, przynajmniej w odniesieniu do polskich bibliotek. Choć tego rodzaju praktyki nie są jeszcze popularne, to jednak można założyć, że skoro grywalizacji ulega oferta biblioteki oraz jej działania promocyjne czy edukacyjne, to również działalność usługowa może z czasem poddać się temu procesowi. 
Obszar działań edukacyjnych i popularyzatorskich bibliotek stosunkowo często jest poddawany procesom grywalizacji. Lekcje biblioteczne, przysposobienie biblioteczne czy kształcenie kompetencji informacyjnych, czytelniczych i medialnych odbywa się za pomocą gier realizowanych tradycyjną metodą: zagadek, zgadywanek itp., jak i w formie gier komputerowych, gier dostępnych w formie aplikacji mobilnych czy na platformach e-learningowych. Gry wykorzystywane są przede wszystkim $\mathrm{w}$ pracy $\mathrm{z}$ młodszym użytkownikiem, rzadziej $\mathrm{w}$ odniesieniu do kształcenia dorosłych, co może świadczyć o stereotypowym ich postrzeganiu jako formy rozrywki dla dzieci i młodzieży. Wyjątek może tutaj stanowić wykorzystanie w bibliotekach tzw. serious games, a więc specyficznego typu gry, w której głównym celem rozgrywki nie jest zabawa, ale zdobycie konkretnych, często zaawansowanych umiejętności (Girard, Ecalle, \& Magnan, 2013). Prowadzenie działań edukacyjnych w bibliotekach przy użyciu serious games nie jest jeszcze bardzo popularne, ale można już znaleźć opisy takich działań, szczególnie w publikacjach anglojęzycznych. Przykładem mogą być działania jednej z bibliotek akademickich, która przygotowała program edukacyjny oparty o serious games dla studentów studiów licencjackich, w którym studenci projektowali własne gry jako odpowiedź na zdiagnozowane przez siebie problemy, np. lęk przed biblioteką (ang. library anxiety) (Bates, 2012).Grywalizacja procesów edukacyjnych może przyczynić się do efektywniejszego i atrakcyjniejszego $\mathrm{w}$ formie przekazywania wiedzy, pomagając budować pozytywne skojarzenia $\mathrm{z}$ biblioteką jako miejscem pozyskiwania informacji.

\section{GRYWALIZACJA PROCESÓW WEWNĘTRZNYCH}

Tematem najrzadziej poruszanym w odniesieniu do możliwości wykorzystania gier w bibliotekach jest kwestia grywalizacji wewnętrznych procesów biblioteki. W firmach komercyjnych mechanizmy grywalizacji są często wykorzystywane w celu zwiększania motywacji pracowników oraz uatrakcyjniania procesu wykonywania żmudnych zadań wymagających koncentracji i powtarzalności. W literaturze przedmiotu można znaleźć opisy eksperymentów pokazujących wysoką skuteczność dobrze przeprowadzonych procesów grywalizacji w zwiększaniu motywacji pracowników i ich zadowolenia z pracy, podkreślając jednak, że podstawą skutecznej grywalizacji jest dobrowolność uczestnictwa w grze i jej prawidłowe zaprojektowanie. Analiza wyników badań empirycznych dotyczących skuteczności procesów grywalizacji przeprowadzona przez Juho Hamari, Jonnę Koivisto i Harriego Sarsa na podstawie analizy literatury przedmiotu prowadzi do konkluzji: „Według większości analizowanych 
badań grywalizacja wywołuje pozytywne skutki i przynosi korzyści" [tłum. własne] ${ }^{2}$ (Hamari, Koivisto \& Sarsa, 2014, p. 3028).

Grywalizacja procesów instytucji publicznych nie jest zagadnieniem często poruszanym $w$ literaturze przedmiotu, $\mathrm{z}$ wyjątkiem tematów związanych $\mathrm{z}$ wdrażaniem grywalizacji $w$ instytucjach edukacyjnych. Trudno znaleźć prace naukowe, które odnosiłyby się do możliwości wykorzystania grywalizacji w bibliotekach np.: w opracowaniu zbiorów czy przeprowadzaniu skontrum. Choć bez wątpienia specyfika pracy bibliotecznej - czy szerzej działalności non profit - różni się znacznie od działalności firm komercyjnych, to jednak można zakładać, że do pewnego stopnia praktyki wdrażane w sektorze komercyjnym mogą być adaptowane do potrzeb bibliotek. Powstają już aplikacje bazujące np. na rozwiązaniach z zakresu rozszerzonej rzeczywistości, przeznaczone do usprawniania procesów wewnętrznych biblioteki np. ShelvAR (projekt obecnie zawieszony z powodu sporów patentowych) (ShelvAR, 2013), które nietrudno byłoby wyposażyć w opcje grywalizacji. Zbadania wymagałby jednak najpierw stosunek bibliotekarzy do tego typu rozwiązań i ich chęć do korzystania $\mathrm{z}$ tego rodzaju aplikacji.

\section{WNIOSKI}

Przeprowadzona analiza pokazała, że gry moga pełnić w bibliotece różne funkcje oraz występować w wielu formach i kontekstach. Mogą przy tym być wykorzystywane zarówno dla celów edukacyjnych, promocyjnych, w usługach bibliotecznych, jak i - przynajmniej teoretycznie - dla usprawniania wewnętrznych procesów bibliotecznych. Gry moga przy tym stanowić element oferty bibliotecznej, realizowanej tak w budynku biblioteki, jak również w przestrzeni miejskiej. Niektóre z wymienionych zastosowań gier, przede wszystkim te związane edukacją i promocją są już na szeroką skalę wdrażane w bibliotekach i opisywane w publikacjach naukowych, część niesie ze sobą potencjał, który nie jest jeszcze w pełni wykorzystywany w bibliotekach, ale mógłby przynieść korzyści.

Podsumowując można stwierdzić, że popularność gier wśród różnych grup użytkowników - nie tylko wśród dzieci i młodzieży, ale także dorosłych - sprawia, że jest to narzędzie, którego nie można ignorować. Ciekawa forma wizualna wielu gier i ich angażujący charakter mogą pomóc bibliotekom w realizowaniu ich zadań w atrakcyjny - zarówno dla użytkowników, jak i bibliotekarzy - sposób. Umiejętne wykorzystanie gier w działalności bibliotecznej może także korzystnie wpłynąć na budowanie wizerunku bibliotek jako nowoczesnych i przyjaznych instytucji, któ-

\footnotetext{
${ }^{2}$ Cytowany fragment w oryginale: „According to a majority of the reviewed studies, gamification does produce positive effects and benefits" (Hamari, Koivisto \& Sarsa, 2014, p. 3028)
} 
re potrafią dostrzegać nowe trendy i czerpać z nich inspirację dla swoich działań.

\section{BIBLIOGRAFIA}

Adams, Ernest (2013). Fundamentals of Game Design. Berkeley: New Riders.

Bates, Matthew, et al. (2012). Exploring university library induction within an undergraduate serious games design module. In: Proceedings of the 6 th European Conference on Games Based Learning: ECGBL. Ed. by P. Felicia. Reading: Academic Conferences Limited, pp. 48-55.

Battles, Jason; Glenn, Valerie; Shedd, Lindley (2011). Rethinking the library game: Creating an alternate reality with social media. Journal of Web Librarianship, vol. 5/2, pp. 114-131.

Biblioteka inspiruje czyli rodzinna gra miejska w...bibliotece [online], [dostęp: 30.04.2018]. Dostępny w WWW: <http://www.mbp.chrzanow.pl/str_mbp/relacje-z-wydarzen/1459-biblioteka-inspiruje-czyli-rodzinna-gra-miejska-w-bibliotece.html>.

Bonk, Gabriela (2013). Konkursy i turnieje w bibliotece. Warszawa: Dr Josef Rabe Spółka Wydawnicza.

Curyło, Monika (2014). „Kampania czytelnicza” czyli propaganda książki. Akcje społeczne promujące książkę, czytelnictwo i bibliotekę. W: Sfera kultury, sfera nauki: wspótczesny obraz biblioteki. Red. M. Wojciechowska. Gdańsk: Oficyna Wydawnicza Edward Mitek, s. $87-110$.

Curyło, Monika (2015). Gra miejska jako forma promocji biblioteki akademickiej. W: Biblioteki bez użytkowników...? Diagnoza problemu, V Ogólnopolska Konferencja Naukowa, Supraśl, 14-16 września 2015. Red. H. Brzezińska-Stec, J. Żochowska. Białystok: Wydaw. Uniwersytetu w Białymstoku, s. 375-389.

Dongying, Zhou; Chengyue, Wang (2017). Game Service and Children Reading Promotion: Taking Changshu Library as an Example. Libraly Journal, 36/6, pp. 61-66.

Girard, Coralie; Ecalle, Jean; Magnan, Anne (2013). Serious games as new educational tools: how effective are they? A meta-analysis of recent studies. Journal of Computer Assisted Learning, 29/3, pp. 207-219.

Gra miejska [online], [dostęp: 10.05.2018]. Dostępny w WWW: <http://mbp-oswiecim.pl/ gra-miejska/>.

Gra miejska Czas Znaków z „Signum Sanguinem” [online], [dostęp: 15.03.2018]. Dostępny w WWW: <http://iii-lo- kalisz.wixsite.com/kopernik-biblioteka/single-post/2016/12/04/ Gra- miejska-CZAS-ZNAK\%C3\%93W-z-Signum-Sanguinem>.

Gra mobilna „Tajemnica biblioteki" [online], [dostęp: 20.09.2018]. Dostępny w WWW: https:// www.wroclaw.pl/go/wydarzenia/edukacja-i-rozwoj/1262043-gra-mobilna-tajemnicabiblioteki.

Gra planszowa Skryptorium i Ora Et Labora [online], [dostęp: 30.04.2018]. Dostępny w WWW: $<$ https://produktybenedyktynskie.com/p1803,gra-planszowa-skryptorium-i-ora-et-labora>.

Hamari, Juho; Koivisto, Jonna; Sarsa, Harri (2014). Does gamification work?--a literature review of empirical studies on gamification. In: System Sciences (HICSS), 2014 47th Hawaii International Conference. Ed. R. H. Sprague. Piscataway: IEEE, pp. 3025-3034.

Jaskowska, Bożena (2013). W to nam graj! Grywalizacja w promowaniu usług bibliotecz- 
nych. W: Biblioteka jako marka: materiały z VII Forum Młodych Bibliotekarzy w Łodzi, 11-12 września 2012 r. Red. J. Stawińska. Warszawa: Wydaw. SBP [online], [dostęp: 30.04.2018]. Dostępny w WWW: <https://repozytorium.ur.edu.pl/handle/item/127?show=full>.

Juul, Jesper (2011). Half-real: Video games between real rules and fictional worlds. Cambridge: MIT press.

Koszowska, Agnieszka (2009). „Trzecie miejsce” wedtug Raya Oldenburga [online], [dostęp: 20.09.2018]. Dostępny w WWW: <http://blog.biblioteka20.pl/?p=149>.

Kubisiak, Aneta (2016). Jak grać, aby wygrać - czyli kilka pomysłów na „ściągnięcie” czytelników do biblioteki." Biuletyn EBIB, nr 167, s. 1-5.

LARP Zaczytani w bibliotece [online], [dostęp: 13.04.2018]. Dostępny w WWW: <https:// www.facebook.com/events/441811462605609/>.

Margino, Megan (2013). Revitalizing traditional information literacy instruction: Exploring games in academic libraries. Public Services Quarterly, vol. 9/4, pp. 333-341.

Mayer, Brian; Harris, Christopher (2010). Libraries got game: Aligned learning through modern board games. Chicago: American Library Association.

Mól, Katarzyna (2016). Gra biblioteczna jako forma promocji i narzędzie komunikacji z młodym użytkownikiem. Biblioteka i Edukacja, nr 10, s. 1-7 [online], [dostęp: 13.03.2018]. Dostępny w WWW: <http://www.bg.up.krakow.pl/newbie/index.php/bie/article/view/15 9/158.

Pamuła-Cieślak, Natalia (2015). Grywalizacja w bibliotekach - obszary zastosowań [online], [dostęp: 05.03.2018]. Dostępny w WWW: <https://repozytorium.umk.pl/handle/ite$\mathrm{m} / 2364>$.

Przybyszewska, Agnieszka (2017). Literacka immersja i technologia step-in-book, czyli o przenikaniu się światów literackich i rzeczywistych. W: Nowoczesne technologie czy tradycyjne metody? O tendencjach w krzewieniu kultury czytelniczej młodego pokolenia. Red. M. Antczak, A. Walczak-Niewiadomska. Łódź: Wydaw. Uniwersytetu Łódzkiego; Warszawa: Wydaw. SBP, s. 47-60.

ShelvAR [online], [dostęp: 07.03.2018]. Dostępny w WWW: <http://www.shelvar.com/>.

Skrabka, Marcin (2017). Gamifikowanie literatury pięknej na smartfonach, czyli jak tchnąć ducha mobile $\mathrm{w}$ tradycyjne książki. W: W bibliotece wszystko gra - wielofunkcyjna przestrzeń biblioteczna. Opole: Politechnika Opolska [online], [dostęp: 20.09.2018]. Dostępny w WWW: <http://www.dbc.wroc.pl/dlibra/docmetadata?id=38215>.

Stobiecka, Jadwiga; Stobiecki, Paweł (2015). Gamifikacja jako nowe narzędzie marketingu relacji - próba klasyfikacji odbiorców komunikatu. Handel Wewnętrzny, nr 1/354, s. 261-271.

Tydzień Bibliotek 2015 [online], [dostęp: 05.03.2018]. Dostępny w WWW: <http://www.sbp. $\mathrm{pl} /$ konkurs/nagrodzeni?konkurs_id=13255>.

Vrbancic, Emilie K.; Byerley, Suzanne L.(2018). High-touch, low-tech: Investigating the value of an in-person library orientation game. College $\mathcal{E}$ Undergraduate Libraries, vol. 25.1, pp. 39-51.

Wójcik, Magdalena (2014). Gaming w bibliotekach: klasyczne role-playing games a czytelnictwo. Przeglad Biblioteczny, 82/1, s. 41-56.

Wójcik, Magdalena (2016). Nowe metody promocji czytelnictwa w przestrzeni miejskiej. Acta Universitatis Lodziensis. Folia Librorum Acta Universitatis Lodziensis. Folia Librorum, nr 22-23, s. 13-28. 
Zdanowicz, Mateusz (2015). Wiedźmin 3 z nagrodami Golden Joystick Awards w pięciu kategoriach: w tym "Ultimate Game of the Year" [online], [dostęp: 05.03.2018]. Dostępny w WWW: <https://www.eurogamer.pl/articles/2015-10-30-wiedzmin-3-z-nagrodamigolden-joystick-awards-w-pieciu-kategoriach>.

Artykut w wersji poprawionej wpłynąt do Redakcji 20 września 2018 r.

MAGDALENA WÓJCIK

Institute of Information Studies

Jagiellonian University

e-mail: magda.wojcik@uj.edu.pl

\title{
AREAS AND OPTIONS FOR THE USE OF GAMES IN LIBRARY ACTIVITIES
}

KEYWORDS: Libraries. Games. Gamification. Library processes. Library services.

\begin{abstract}
Thesis/Objective - The use of games in libraries is a frequently discussed issue in the literature of the field, yet only as regards the aspect of using them for promotion and PR purposes. The literature misses the discussion of a comprehensive use of games of and gamification phenomenon in various library activities related both to user services and the optimization of internal library processes. The aim of this article is to analyze the areas and options for the use of games in library activities. Research method - The critical analysis of the literature was used. The author analyzed the literature in the field of book and information studies published in Polish and English between 2008 and 2018, related to the issue of using games in the library actitivity. The research was based on such sources as the catalog and databases of the National Library of Poland, the databases of the Jagiellonian Library, WorldCat database, Google Scholar search results browsing various publishers' databases and abstracting databases such as BABIN and LISTA. Results - Games may be used in libraries in various options such as: broad subject games played in the library, games focused on books and libraries, games based on literary works, games that may be used to advertise reading, games conducted outside the library but prepared by its staff, games to be lent from the library, books in the form of games, library services with the elements of gamification, games for educational purposes and the gamification of internal library processes. Conclusions - The analysis shows that games may be used for a variety of purposes in libraries, to educate, promote library services and improve internal library processes.
\end{abstract}


